\title{
THE INFLUENCE OF VIRTUAL TOURS ON ROMANIAN TOURISM
}

\section{Cipriana Sava}

\author{
Christian University "D. Cantemir" \\ Bucharest, \\ Faculty of Tourism and Commercial \\ Management Timişoara \\ Bucharest, Romania
}

\begin{abstract}
:
The aspects of everyday life also influence the choice of destinations for spending free time. It is well known that motivation has a major role, since it is personal, subjective and directly under the influence of endogenous and exogenous impulses. Technology has invaded our lives and can help us choose the appropriate holiday destination.

Virtual tours give a new perspective to those willing to experience a tourist destination, as they are available 24/7, free of charge and easily accessible. Promoting Romanian tourism through modern instruments in the online environment can become an advantage. Numerous tourist resources and locations presented in this way can raise the users' interest, thus urging them to visit such places.
\end{abstract}

Key words:

tourism, online environment, virtual tours, website, promotion.

\section{INTRODUCTION}

The ongoing development of society has given rise to other needs, from natural psychological needs related to the need of water, food, air, clothing, over social needs that can translate by the need of belonging to a social group, networking and joint action with other individuals, and then to the rational, spiritual - psychological needs related to education and higher rational professional thinking.

According to the American psychologist Abraham Maslow, needs could be classified into: physiological, safety, love and belonging, esteem and respect, as well as self-achievement.

Currently, the majority of the population wants to occasionally break away from everyday problems and spend leisure time outside their residences.

The main motivations in choosing tourist destinations are linked to a range of needs, namely relaxation and rest („charging batteries”), knowledge, keeping health or its restoration, integration into a group and comfort, practising sports, entertainment and leisure.

Currently, there is a growing interest in maintaining and beautifying the body, as well as intellectual stimulation (widening the intellectual horizon). It can be said that man travels to feel special. 
Given the reasons presented, the trip can be seen as:

- an initiation;

- an expedition;

- a pilgrimage;

- an access to new places;

- a way of life.

The decision to choose a destination for leisure is influenced by a number of personal impulses or recommendations from close friends and acquaintances.

Increasingly advanced technology also contributes to the choice of the holiday destination.

\section{THE VIRTUAL TOUR}

A tour means a short walk on a chosen route, and virtual refers to something that is only a possibility, not a fact.

The term "virtual tour" was first used in June 1994 to refer to the presentation of the Dudley Castle museum in England. Two specialists, Colin Johnson (Image Interactive) and Peter Bolad (Dudley Metropolitan Borough) made a $3 \mathrm{D}$ reconstruction of the castle, offering visitors a unique "virtual walk" experience. The system conceived in 1994 worked until 2005, but since technology has significantly evolved, today the virtual tour has new meanings.

The virtual tour is based on modern technology to interactively present a location. It is made up of interconnected panoramic images, among which, by means of connections, the transaction can be achieved.

A panoramic image is a photo that can be seen in any direction; it is the basic element of the $360^{\circ}$ virtual tour. A virtual tour consists of at least two spherical panoramic photos.

Briefly, a virtual tour may contain the sketch of the location (floorplan), with rooms and places where panoramas were photographed to facilitate the formation of an objective opinion about the tourist attraction, building, hotel, accommodation facility or food service facility. If the presentation of a geographic area is wanted, virtual tours may contain maps like Google Maps or Yahoo Maps, satellite images, panoramas being geo-located by GPS.

For information to be complete, text and photos can be integrated, placed within the panoramas and associated with them or with certain areas of interest, and displayed through sensitive areas.

Last but not least, it is necessary for a virtual tour to have a friendly navigation interface.
Watching virtual tours is performed using QuickTime, Java, Shockwave Flash and OpenGL plugins. Currently Flash 10 is the best option because over $98 \%$ of users have Flash installed on their PCs, and no other plugins are necessary. Using Flash allows us to provide interactive solutions for the $360^{\circ}$ virtual tour, and the possibility to show full screen panoramas and virtual tours.

These virtual tours can be viewed on any computer and smartphones.

Their presentation can be integrated in the official website presentation of the location, can be posted on social networking sites, distributed on CD, DVD, flash card, etc., or optimized for printing.

The applicability of virtual tours in tourism refers to the presentation of:

- tourist attractions (buildings, castles, fortresses, museums, memorial houses, churches, monasteries, caves, salt mines, etc.);

- accommodation facilities;

- food services facilities;

- leisure spaces;

- exhibitions;

- treatment centres and spas;

- tourist resorts.

There are multiple benefits of using a virtual tour, namely:

- it is available 24 hours a day, 365 days a year from anywhere in the world;

- it presents reality $100 \%$, offers full transparency;

- highlights the strengths of the location / sight;

- gives confidence in the quality and accuracy of provided services;

- the degree of interactivity and accessibility can impress any client;

- it gives the opportunity to explore an area at your own pace, without constraints;

- it presents an increased portability;

- it offers a big advantage over the competition;

- it is the most modern and effective method of promoting a place or a business;

- costs are low compared to other promotion methods;

- the investment for a virtual tour is very low, while the benefits are maximized.

It was found that a virtual tour of a tourist attraction increases the number of visitors, the same goes for the virtual tours of some accommodation facilities where the number of online bookings and occupancy has signifi- 
cantly increased. If users are presented a virtual tour, the probability that they make an online booking is twice as high. Users aged between 18 and 34 years are by $130 \%$ more inclined to make a reservation after seeing such a tour.

\section{VIRTUAL TOURS IN ROMANIAN TOURISM}

Romania is one of the countries bordering the Black Sea, located on the north-western shore, in the southeast of Central Europe. Its total area is $238391 \mathrm{~km}^{2}$ plus $23700 \mathrm{~km}^{2}$ from the Black Sea platform.

Due to its geographical position, relief and climate, hydrographic network, history, and cultural values, various forms of tourism like coastal tourism, mountain, countryside, spa, transit, business, cultural, scientific, religious tourism, agro tourism, ecotourism can be practiced on the territory of the country.

In order to analyse the evolution of the number of tourists and their preferences, some categories of tourist destinations were marked off, namely:

- resorts;

- coastal resorts;

- mountain resorts;

- the Danube Delta;

- the capital city and the county capitals;

- other destinations

The evolution of the number of tourist arrivals in Romania in recent years has been increasing, oscillating only between the selected destinations (Table 1)

\begin{tabular}{cccccc}
\hline $\begin{array}{c}\text { Tourist destina- } \\
\text { tion }\end{array}$ & $\begin{array}{c}\text { Year } \\
\mathbf{2 0 1 0}\end{array}$ & $\begin{array}{c}\text { Year } \\
\mathbf{2 0 1 1}\end{array}$ & $\begin{array}{c}\text { Year } \\
\mathbf{2 0 1 2}\end{array}$ & $\begin{array}{c}\text { Year } \\
\mathbf{2 0 1 3}\end{array}$ & $\begin{array}{c}\text { Year } \\
\mathbf{2 0 1 4}\end{array}$ \\
\hline Resorts & 568257 & 689195 & 696180 & 678536 & 655565 \\
\hline Coastal resorts & 702566 & 735881 & 804198 & 728748 & 747103 \\
\hline $\begin{array}{c}\text { Mountain } \\
\text { resorts }\end{array}$ & 814973 & 962415 & 1121238 & 1241133 & 1291013 \\
\hline $\begin{array}{c}\text { The Danube } \\
\text { Delta }\end{array}$ & 68414 & 81567 & 88021 & 80885 & 65604 \\
\hline $\begin{array}{c}\text { Bucharest and } \\
\text { the county } \\
\text { capitals }\end{array}$ & 3011688 & 3541409 & 3816873 & 3983497 & 4308117 \\
\hline $\begin{array}{c}\text { Other localities } \\
\text { and tourist trails }\end{array}$ & 906859 & 1021139 & 1159979 & 1230354 & 1398507 \\
\hline
\end{tabular}

TOTAL 60727577031606768648979431538465909

Table 1. Evolution of the number of tourist arrivals according to tourist destinations - No. of tourists

Source: TUR 104C Tempo Online time series, www.insse.ro
It could be noted that the number of tourists has increased annually at resorts in the mountain area (new resorts have opened and existing facilities have been modernized), the capital city and the county capitals (promoting city break, organizing various events), and at other localities and tourist routes.

The tourists registered in 2014 in the capital city, in Sibiu (European Capital of Culture in 2007) and Bran (Bran Castle - Dracula myth) preferred September, October and August (Table 2)

\begin{tabular}{cccc}
\hline Month & Bucharest & Sibiu & Bran \\
\hline January & 80834 & 15075 & 4059 \\
\hline February & 95114 & 16445 & 4714 \\
\hline March & 120721 & 15793 & 4088 \\
\hline April & 111122 & 18626 & 4527 \\
\hline May & 142027 & 26343 & 4257 \\
\hline June & 141962 & 26240 & 6215 \\
\hline July & 125197 & 24790 & 7259 \\
\hline August & 131688 & 31860 & 9367 \\
\hline September & 157382 & 26058 & 6191 \\
\hline October & 157606 & 21112 & 5805 \\
\hline November & 137846 & 19309 & 5255 \\
\hline December & 108723 & 17160 & 5129 \\
\hline Total & 1510222 & 258811 & 66866 \\
\hline
\end{tabular}

Table 2. Distribution of tourists by months in 2014. - No. of tourists

Source: TUR 104H Tempo Online-statistical series, www.insse.ro

Business, cultural and scientific tourism is present in Bucharest, while Sibiu and Bran are well known for leisure, recreation, cultural, historical and event tourism.

An issue that the Romanian tourism is still facing is the small share of foreign tourist arrivals (Table 3).

Attracting a larger number of tourists, especially foreigners, can also be achieved through a more sustained promotion in the online environment.

In Romania, 10.3 million people use the Internet (Romanian Audit Bureau Transmedia - BRAT), that is $68 \%$ of the population aged between 16 and 64 use the internet, while worldwide there are over three billion people using the Internet (International Telecommunication Union - ITU), therefore the possibility of people knowing the Romanian tourism offer is extremely high. 


\begin{tabular}{cccccc}
\hline Indicator & 2010 & 2011 & 2012 & 2013 & 2014 \\
\hline $\begin{array}{c}\text { Romanian } \\
\text { tourists (no. } \\
\text { of persons) }\end{array}$ & 4726414 & 5514907 & 6030053 & 6225798 & 6551339 \\
\hline $\begin{array}{c}\text { Foreign tour- } \\
\text { ists (no. of } \\
\text { persons) }\end{array}$ & 1346343 & 1516699 & 1656436 & 1717355 & 1914570 \\
\hline $\begin{array}{c}\text { Share of for- } \\
\text { eign tourists } \\
(\%)\end{array}$ & 22,17 & 21,60 & 21,55 & 21,62 & 22,61 \\
\hline
\end{tabular}

Table 3. Evolution of foreing tourist arrivals in Romania Source: TUR 104C Tempo Online time series, www.insse.ro, processed data

Virtual tours are currently the most modern technology used for the presentation of a location.

There are numerous tourist attractions, accommodation and food services and facilities in Romania that have their presentation via virtual tours, some of which are summarized in Table 4.

Virtual tours have increased people's interest in the tourist attraction, accommodation or food service facility presented. Such tours can be found in Bucharest, Sibiu, Bran and we can say that the number of tourists registered per year and per month shows the growing interest of tourists.

Making more quality virtual tours has a positive bearing on tourist traffic in Romania.

\section{CONCLUSIONS}

Interactive virtual tours are currently the most innovative technology used for presenting tourist destinations and it allows for effective marketing strategies.

If a virtual tour is well done, it can make any user feel present in the visited space. Watching a virtual tour is extremely easy, the user being able to control his movement within the area, zoom in and out, and being able to focus on the areas that draw his attention.

More and more websites display virtual tours that seek to convince users to buy tourism services. In the case of accommodation facilities, in general, a significant increase could be observed in online bookings.

Romanian tourism can be positively influenced by the existence of these virtual tours accessible to an extremely high number of people, both in the country and worldwide.

\begin{tabular}{|c|c|c|}
\hline Tourist attraction & Location & Link \\
\hline CurteaVeche Museum & Bucharest & http://360.inp.org.ro \\
\hline Romanian Atheneum & Bucharest & http://gratuitor.ro/tur-virtual-al-ateneului-roman/ \\
\hline Aviation Museum & Bucharest & http://www.360trip.ro/muzeulaviatiei \\
\hline Bran Castle & Bran, Braşov County & http://www.castelulbran.ro/ \\
\hline Black Church & Braşov & http://turism.brasovcity.ro/index.php/tururi/detail/12 \\
\hline History Museum & $\begin{array}{l}\text { Sighişoara, Mureş } \\
\text { County }\end{array}$ & http://sighisoara360.ro/sighisoara/muzeuldeistorie \\
\hline Brukenthal Museum & Sibiu & http://www.sibiul.ro/sibiu-virtual-tour/sibiu-virtual-tour-68.html \\
\hline Astra Museum & Sibiu & http://muzeulastra.ro/vizitare/vizita-virtuala.html \\
\hline $\begin{array}{l}\text { Peleş Castle interior- } \\
\text { exterior }\end{array}$ & Sinaia, Prahova County & https://www.youtube.com/watch?v=CqhAUZHBvps \\
\hline $\begin{array}{l}\text { Sarmizegetusa } \\
\text { Archaeology Museum }\end{array}$ & $\begin{array}{l}\text { Sarmizegetusa, } \\
\text { Hunedoara County }\end{array}$ & $\begin{array}{l}\text { http://muzeu.geomatic.ro/sectii/sarmis/sarmi_virtual/ro/2/2 } \\
\text { amfiteatru.htm }\end{array}$ \\
\hline Corvinilor Castle & Hunedoara & https://www.city3d.ro/castelul-huniazilor-hunedoara-city3d \\
\hline Turda Salt mine & Turda, Cluj County & http://www.qbox.ro/salina-turda/tur-virtual-1974.html \\
\hline Hotel Aro Palace & Braşov & http://www.aro-palace.ro/tururi-virtuale/hotel-brasov-aro-palace.html \\
\hline Siago Pension & Cluj-Napoca & http://www.pensiuneasiago.ro/tur-virtual.php \\
\hline $\begin{array}{l}\text { Caru cu Bere } \\
\text { Restaurant }\end{array}$ & Bucharest & http://www.vederepanoramica.ro/tur-virtual-caru-cu-bere \\
\hline Transfăgăraşan & $\begin{array}{l}\text { Făgăraş Mountains, } \\
\text { Southern Carpathians }\end{array}$ & $\begin{array}{l}\text { http://www.360cities.net/image/transfagaran-virtual-tour-360- } \\
\text { romania-fagaras }\end{array}$ \\
\hline
\end{tabular}

Table 4. Virtual tours for tourism promotion - examples 


\section{REFERENCES}

Barza, V. (2015, May). Numărul utilizatorilor de internet ajunge la 3,2 miliarde. Retrieved March 12, 2016, from http://economie.hotnews.ro/stiri-it20190032-numarul utilizatorilor-internet-ajunge3-2-miliarde.htm

Sava, C. (2010). Economia turismului [The economy of tourism]. Timişoara: Ed. Eurostampa.

Stanca, A. (2015, March). Peste 10 milioane de români au acces la internet. Care este profilul utilizatorului din mediul rural. Retrieved March 12, 2015, from http://www.gandul.info/it-c/peste-10-milioanede-romani-au-acces-la-internet-care-este-profilulutilizatorului-din-mediul-rural-13936734
TUR 104C, 104H. (2015, March). Tempo Online time series. Retrieved March 4, 2016, from www.insse.ro

Services offered. Retrieved February 21, 2016, from http:// info3d.ro/

Virtual tours. Retrieved March 12, 2016, from http:// www.sitto360.ro//tururi-virtuale.php 